\title{
Photoperiod-Dependent Effects of 4-tert-Octylphenol on Adherens and Gap Junction Proteins in Bank Vole Seminiferous Tubules
}

\author{
Anna Hejmej, Malgorzata Kotula-Balak, Katarzyna Chojnacka, Paulina Kuras, \\ Marta Lydka-Zarzycka, and Barbara Bilinska
}

Department of Endocrinology, Institute of Zoology, Jagiellonian University, Gronostajowa 9, 30-387 Krakow, Poland

Correspondence should be addressed to Anna Hejmej; anna.hejmej@uj.edu.pl

Received 10 December 2012; Revised 2 April 2013; Accepted 5 April 2013

Academic Editor: Radmila Kovacevic

Copyright (C) 2013 Anna Hejmej et al. This is an open access article distributed under the Creative Commons Attribution License, which permits unrestricted use, distribution, and reproduction in any medium, provided the original work is properly cited.

\begin{abstract}
In the present study we evaluated in vivo and in vitro effects of 4-tert-octylphenol (OP) on the expression and distribution of adherens and gap junction proteins, $\mathrm{N}$-cadherin, $\beta$-catenin, and connexin 43 (Cx43), in testes of seasonally breeding rodents, bank voles. We found that in bank vole testes expression and distribution of $\mathrm{N}$-cadherin, $\beta$-catenin, and $\mathrm{Cx} 43$ were photoperiod dependent. Long-term treatment with OP $(200 \mathrm{mg} / \mathrm{kg} \mathrm{b.w.)} \mathrm{resulted} \mathrm{in} \mathrm{the} \mathrm{reduction} \mathrm{of} \mathrm{junction} \mathrm{proteins} \mathrm{expressions}(P<0.05$, $P<0.01)$ and their delocalization in the testes of males kept in long photoperiod, whereas in short-day animals slight increase of Cx43 $(P<0.05), \mathrm{N}$-cadherin, and $\beta$-catenin (statistically nonsignificant) levels was observed. Effects of OP appeared to be independent of FSH and were maintained during in vitro organ culture, indicating that OP acts directly on adherens and gap junction proteins in the testes. An experiment performed using an antiestrogen ICI 182,780 demonstrated that the biological effects of $\mathrm{OP}$ on $\beta$-catenin and $\mathrm{Cx} 43$ involve an estrogen receptor-mediated response. Taken together, in bank vole organization of adherens and gap junctions and their susceptibility to OP are related to the length of photoperiod. Alterations in cadherin/catenin and Cx43based junction may partially result from activation of estrogen receptor $\alpha$ and/or $\beta$ signaling pathway.
\end{abstract}

\section{Introduction}

Alkylphenols (e.g., 4-tert-octylphenol, OP; 4-tert-nonylphenol, NP) and alkylphenol ethoxylates are a group of endocrine-disrupting chemicals that accumulate at high concentrations in air, soil and aquatic environment from the use of detergents, paints, pesticides, and plastic manufacturing [1]. They are also found in the fluids and body fat of animals and humans [2]. These compounds are classified as xenoestrogens, since they are able to induce inappropriate estrogenic action or interfere with the actions of endogenous estrogens affecting reproductive development and functions of laboratory and wild animals, and most likely humans [3]. Alkylphenols bind to the nuclear estrogen receptors (ERs), but their binding affinity and ability to activate ER-mediated functions is $100-10,000$ times less potent than that of $17 \beta$ estradiol [4]. However, they exhibit quite robust nongenomic activity [5]. Since 2000, European Union restricted use of alkylphenols as priority hazardous substances by Directive 2000/60/EC [6]. Nevertheless, they are still detected world widely in the environment and organisms [7]. Recent analyses indicate that although alkylphenol ethoxylates levels have been decreasing in the last years, Europe is much more contaminated than North America and developing countries [1].

Spermatogenesis, a process by which spermatogonia undergo a series of divisions and differentiation to become spermatozoa, is tightly controlled by Sertoli cells. Direct interactions between Sertoli cells and between Sertoli and germ cells are mediated by proteins that form specialized cell junctions. $\mathrm{N}$-cadherin and $\beta$-catenin are constituent proteins of testicular adherens junctions. They form complexes localized between Sertoli cells at the site of blood-testis barrier (BTB) and between Sertoli cells and elongated spermatids, in the apical ectoplasmic specializations. Cadherin/catenin complexes play a determining role in stabilizing cell-cell 
contacts and their restructuring during movement of preleptotene spermatocytes across the BTB. It was reported that the altered expression or loss of the protein-protein interactions between $\mathrm{N}$-cadherin and $\beta$-catenin induces germ cell detachment from the seminiferous epithelium $[8,9]$. Connexin 43 (Cx43), the predominant gap junction protein in seminiferous epithelium, is of absolute requirement for normal testicular development and spermatogenesis [10]. In adult testis $\mathrm{Cx} 43$ is a component of the junctional complex enabling direct communication and exchange of small molecules between adjacent Sertoli cells, Sertoli and germ cells, and between Leydig cells. Recent studies provided clear evidence that $\mathrm{Cx} 43$ can also control spermatogenesis through regulation of tight and anchoring junctions that are closely intermingled with each other at the site of the BTB [11].

Recent papers have reported that xenoestrogens can affect spermatogenesis by perturbing direct cell-cell interactions in the seminiferous epithelium. Extensively studied xenoestrogen bisphenol A was demonstrated to cause a dosedependent reduction in several junction proteins (including $\mathrm{N}$-cadherin, $\beta$-catenin, and $\mathrm{Cx} 43$ ) in Sertoli cells in vitro and to disrupt the BTB when administered to immature rats $[12$, 13]. The estrogenic actions of alkylphenols on the testis are less studied when compared with bisphenol A. Although it was demonstrated that exposure to OP or NP induces changes in multiple gene transcription, cell proliferation, and hormone production in vitro and in vivo, scarce data are available on their influence on junction proteins in the testes [14-16].

In our previous study bank voles, seasonally breeding rodents, were used to investigate the effects of OP on male reproductive organs, depending on the length of exposure and reproductive status of animals [17]. We found that longterm exposure of adult males affected expressions of $3 \beta$ hydroxysteroid dehydrogenase, aromatase, estrogen receptor $\alpha$, and androgen receptor as well as sex steroids levels in the testes and seminal vesicles. Concomitantly, increased apoptosis and, occasionally, germ cell sloughing were found. Interestingly, a subtle difference in the sensitivity to OP between voles kept in different light conditions was noted [17]. To better understand the mechanism of OP-induced alterations in the testis, the present study was aimed to examine changes in the distribution and expression of cell junction proteins, $\mathrm{N}$-cadherin, $\beta$-catenin, and connexin 43 , in bank vole following OP exposure in vivo. Importantly, to our knowledge this is the first in vivo study on the effect of OP on adherens and gap junction proteins in the testes. In addition, to evaluate potential direct effects of OP on junction protein expressions in seminiferous epithelium and to examine whether these effects are mediated through binding OP to ERs, organ culture model was used.

\section{Material and Methods}

2.1. Animals. Bank voles (Clethrionomys glareolus, Schreber) were obtained from our own colony (Department of Endocrinology, Institute of Zoology, Jagiellonian University, Krakow, Poland) which have been reared under long light cycles (18 h light and $6 \mathrm{~h}$ darkness; 18L :6D) or short light cycles (6 h light and $18 \mathrm{~h}$ darkness; 6L:18D). The animal rooms were maintained at a temperature of $18^{\circ} \mathrm{C}$ and a relative humidity of $55 \pm 5 \%$. Voles were housed in polyethylene cages $\left(42 \times 27 \times 18 \mathrm{~cm}^{3}\right)$ furnished with sawdust and wood shavings for bedding. A standard pelleted diet (LSM diet, Agropol, Motycz, Poland; total isoflavone content below $450 \mathrm{mg} / \mathrm{kg}$ diet) supplemented with seeds of wheat or oat, red beet, apples, and water was provided ad libitum.

2.2. Exposure In Vivo. Twenty-four mature male bank voles (60-70-day-old) kept in long light cycles (18L:6D, $n=12$ ) and short light cycles $(6 \mathrm{~L}: 18 \mathrm{D}, n=12)$ were dosed orally with 4-tert-octylphenol (OP, $200 \mathrm{mg} / \mathrm{kg}$ body weight; SigmaAldrich, St Louis, MO, USA) every Monday, Wednesday, and Friday for 30 (OP30) or 60 days (OP60). A total of four experimental groups were formed ( $n=6$ /each group). 4-tertoctylphenol was dissolved in a minimum amount of absolute ethanol and then a measured amount of sesame oil (SigmaAldrich, St Louis, MO, USA) was added in 1:14 (v/v), as previously described in detail [17]. A dose of exposure to OP was based on the literature $[15,18]$ and it was finally selected upon our preliminary study in which lower doses (50 and $100 \mathrm{mg} / \mathrm{kg}$ body weight) had no effects on bank vole reproductive organs weight and morphology.

The control animals $(n=24)$ for each experimental group ( $n=6 /$ each group) were given a vehicle only (ethanol + sesame oil). After the animals were sacrificed by cervical dislocation, testes were immediately excised and serum was collected and frozen in $-20^{\circ} \mathrm{C}$.

2.3. Ethics of Experimentation. Experiments were performed in accordance with Polish legal requirements, under the license given by the Local Ethics Committee at the Jagiellonian University, Krakow, Poland (No. 88/IV/2010).

2.4. Tissue Preparation. For immunohistochemical analysis one testis from each animal was immersed immediately in $4 \%$ formaldehyde and embedded in paraplast (Sigma-Aldrich, St Louis, MO, USA). Sections of $5 \mu \mathrm{m}$ in thickness were mounted on slides coated with 3-aminopropyltriethoxysilane (Sigma-Aldrich, St Louis, MO, USA), deparaffinized, and rehydrated through decreasing alcoholic solutions. For Western blot and ELISA analysis, contralateral testis from each animal was frozen and stored in $-80^{\circ} \mathrm{C}$.

2.5. Organ Culture and Exposure In Vitro. Twenty-four untreated male bank voles (60-70-day-old) reared under long light cycles or short light cycles were sacrificed and testes were immediately removed and trimmed free of excess fat and connective tissue. After the capsule had been removed, the testes were cut into small pieces of $2-3 \mathrm{~mm}$ in diameter and were placed on Millipore filters (pore size $0.4 \mu \mathrm{m}$ ) (Millipore Corporation, Billerica, MA, USA). The filters were floated on $1.5 \mathrm{~mL}$ culture Waymouth's media (Gibco, Grand Island, NY, USA) supplemented with 5\% fetal bovine serum (SigmaAldrich, St Louis, MO, USA) and L-glutamine containing $50 \mathrm{U} / \mathrm{mL}$ penicillin, $50 \mu \mathrm{g} / \mathrm{mL}$ streptomycin in tissue culture dishes and incubated at $37^{\circ} \mathrm{C}$, in a humidified atmosphere 
containing $95 \%$ air: $5 \% \mathrm{CO}_{2}$, for $24 \mathrm{~h}$. 4-tert-octylphenol and ICI 182,780 (Sigma-Aldrich, St Louis, MO, USA) were dissolved in absolute ethanol and the final concentration of the solvent in culture medium was $0.1 \%(\mathrm{v} / \mathrm{v})$.

In the first experiment the response to OP was measured by comparing the testes from $18 \mathrm{~L}: 6 \mathrm{D}$ and $6 \mathrm{~L}: 18 \mathrm{D}$ males cultured in medium containing OP (at doses 10, 100, and $500 \mathrm{mg} / \mathrm{L}$ ) with the testes cultured in medium containing solvent (control). In the second experiment (to examine the mechanism of OP action) testes were cultured in medium containing OP (at doses 10, 100, and $500 \mathrm{mg} / \mathrm{L}$ ) or ICI $(6 \mathrm{mg} / \mathrm{L})$, or combination of each dose of OP plus $6 \mathrm{mg} / \mathrm{L}$ ICI. As a control, testes were exposed to medium containing solvent.

Doses of exposure were based on the literature [19]. Lower doses of OP $(0.1,1 \mathrm{mg} / \mathrm{L})$ and ICI $(2 \mathrm{mg} / \mathrm{L})$ were tested in preliminary study. Since they appeared to have no effect on junction proteins, the data were not presented herein. After culture, the media and testes were collected and stored at $-20^{\circ} \mathrm{C}$ and $-80^{\circ} \mathrm{C}$, respectively.

2.6. Immunohistochemistry. To optimize immunohistochemical staining, slices were immersed for $4 \mathrm{~min}$ in $10 \mathrm{mM}$ citrate buffer ( $\mathrm{pH}$ 6.0) and heated in a microwave oven $(600 \mathrm{~W})$. The whole procedure has been described in detail elsewhere [20]. In short, nonspecific staining was blocked twice, first with $3 \% \mathrm{H}_{2} \mathrm{O}_{2}$ in methanol for $15 \mathrm{~min}$, to inhibit endogenous peroxidase activity, and second with $10 \%$ normal goat or horse serum (Sigma-Aldrich, St Louis, MO, USA) for $30 \mathrm{~min}$ at room temperature to block nonspecific binding sites. Thereafter, sections were incubated overnight at $4^{\circ} \mathrm{C}$ in a humidified chamber in the presence of primary antibodies: (1) a mouse monoclonal antibody against $\mathrm{N}$-cadherin (1:100; Invitrogen, Eugene, OR, USA); (2) a rabbit polyclonal antibody against $\beta$-catenin $(1: 300$; Invitrogen, Eugene, OR, USA); (3) a rabbit polyclonal antibody against $\mathrm{Cx} 43$ (1:2,000; Sigma-Aldrich, St Louis, MO, USA). Next, biotinylated secondary antibody, goat anti-rabbit IgG or horse antimouse IgG, respectively (1:400; Vector Labs., Burlingame, CA, USA) was applied for $1 \mathrm{~h}$. Finally, avidin-biotinylated horseradish peroxidase complex (Vectastain ABC Kit; 1:100; Vector Labs., Burlingame, CA, USA) for a further $30 \mathrm{~min}$ was used. After each step in these procedures, sections were carefully rinsed with Tris-buffered saline (TBS; $0.05 \mathrm{M}$ Tris- $\mathrm{HCl}$ plus $0.15 \mathrm{M} \mathrm{NaCl}, \mathrm{pH} 7.6$ ). Bound antibody was visualized with TBS containing $0.05 \% 3,3^{\prime}$-diaminobenzidine (Sigma-Aldrich, St Louis, MO, USA) and $0.07 \%$ imidazole (Sigma-Aldrich, St Louis, MO, USA) for 3-4 min. The slides were processed immunohistochemically at the same time with the same treatment so that the staining intensities among testicular cells could be compared. Experiments were repeated three times on serial sections per animal. Control sections included omission of the primary antibody. The sections were examined with a Leica DMR microscope (Leica Microsystems, Wetzlar, Germany).

2.7. Western Blot Analysis. Tissues were homogenized on ice with a cold RIPA buffer (Sigma-Aldrich, St Louis, MO,
USA), sonicated, and centrifuged at $15,000 \mathrm{~g}$ for $20 \mathrm{~min}$ at $4^{\circ} \mathrm{C}$. The protein concentration for each sample was estimated using Bradford dye-binding procedure with bovine serum albumin (Sigma-Aldrich, St Louis, MO, USA) as a standard. Homogenates containing $100 \mu \mathrm{g}$ of protein were solubilized in a sample buffer (Bio-Rad Labs. GmbH, München, Germany) and boiled for $3 \mathrm{~min}$. After denaturation the samples were subjected to electrophoresis on $10 \%$ polyacrylamide gels. Separated proteins were transferred onto a polyvinylidene difluoride (PVDF) membrane (Millipore Corporation, Billerica, MA, USA) using a wet blotter in the Genie Transfer Buffer (pH 8.4) for $90 \mathrm{~min}$ at a constant voltage of $135 \mathrm{~V}$. Then blots were blocked with 5\% nonfat dry milk in TBS, $0.1 \%$ Tween 20 for $1 \mathrm{~h}$ with shaking, followed by an incubation with appropriate primary antibody (as for immunohistochemistry; anti-Ncadherin, dilution $1: 250$; anti- $\beta$-catenin, dilution $1: 800$; anti$\mathrm{Cx} 43$, dilution $1: 10,000)$ overnight at $4^{\circ} \mathrm{C}$. The membranes were washed and incubated with the horseradish-peroxidase labeled goat anti-rabbit IgG or horse anti-mouse IgG (Vector Labs., Burlingame, CA, USA) at a dilution 1:3,000, for $1 \mathrm{~h}$ at room temperature. Immunoreactive proteins were detected by chemiluminescence with Western Blotting Luminol Reagent (Santa Cruz Biotechnology, Santa Cruz, CA, USA), and images were captured with a ChemiDoc XRS+ System (Bio-Rad Labs. GmbH, München, Germany). All immunoblots were stripped with stripping buffer containing $62.5 \mathrm{mM}$ Tris-HCL, $100 \mathrm{mM}$ 2-mercaptoethanol and 2\% SDS (wt/vol) $(\mathrm{pH} 6.7)$ at $50^{\circ} \mathrm{C}$ for $30 \mathrm{~min}$, and incubated in a rabbit polyclonal antibody against $\beta$-actin (dilution, $1: 3,000$; Sigma-Aldrich) which served as a loading control. Each data point was normalized against its corresponding $\beta$-actin data point. Molecular masses were estimated by reference to standard proteins (Fermentas, GmbH, St. LeonRot, Germany). To obtain quantitative results, immunoblots were scanned using Image Lab 2.0 (Bio-Rad Labs. GmbH, München, Germany).

2.8. ELISA Assay. Plasma FSH concentrations were measured with commercially available Mouse Follitropin subunit beta ELISA Kit (EIAab, Wuhan, China) according to the manufacturer's instructions. The sensitivity of the assay was $0.01 \mathrm{mIU} / \mathrm{mL}$. The measurements were performed in duplicate.

2.9. Statistical Analysis. All statistical analyses were performed using one-way analysis of variance (ANOVA). Tukey multiple comparison test was used to determine which values differed significantly from controls $\left({ }^{*} P<0.05,{ }^{* *} P<0.01\right.$, $\left.{ }^{* * *} P<0.001\right)$. Data were presented as mean \pm SD.

\section{Results}

3.1. In Vivo Experiment. In control males expression and distribution of $\mathrm{N}$-cadherin, $\beta$-catenin, and $\mathrm{Cx} 43$ were dependent on the length of the photoperiod. In seminiferous tubules of 18L:6D animals strong, linear staining for $\mathrm{N}$ cadherin and $\beta$-catenin was localized at the region of BTB, running parallel to the basement membrane. Additionally, 
discrete punctuate staining was observed in the adluminal compartment, mainly at Sertoli cell-elongated spermatid interface (Figures 1(a) and 1(e)). Cx43 was detected predominantly at the base of the tubules, between Sertoli cells and spermatogonia or pachytene spermatocytes as well as in the cytoplasm of some Sertoli cells. A moderate staining was also seen at Sertoli cell-spermatid junctions (Figure 1(i)). The localization and intensity of $\mathrm{N}$-cadherin, $\beta$-catenin, and $\mathrm{Cx} 43$ immunostaining displayed some evidence of stage-specificity. In the Leydig cells, a very strong linear $\mathrm{Cx} 43$ signal on the plasma membrane was found as the prevalent staining pattern (Figure 1(i)).

In tubules of $6 \mathrm{~L}: 18 \mathrm{D}$ animals the intensity of $\mathrm{N}$-cadherin and $\beta$-catenin staining in the basal region of the epithelium was clearly reduced when compared to $18 \mathrm{~L}$ : $6 \mathrm{D}$ voles; weak, punctuate signal extended through much of the epithelium (Figures $1(\mathrm{c})$ and $1(\mathrm{~g})$ ). Similarly as in 18L : 6D animals, $\mathrm{Cx} 43$ was present predominantly in the basal compartment, however its distribution at the region of BTB was irregular and discontinuous. In the adluminal compartment weak staining was frequently dispersed in the cytoplasm of Sertoli or germ cells (Figure 1(k)). Cytoplasmic staining was also detected in Leydig cells of 6L:18D males (insert in Figure 1(k)).

Exposure to OP for 30 days did not alter the distribution of $\mathrm{N}$-cadherin, $\beta$-catenin, and $\mathrm{Cx} 43$ neither in $18 \mathrm{~L}: 6 \mathrm{D}$ nor $6 \mathrm{~L}: 18 \mathrm{D}$ males (not shown). In males treated with OP for 60 days distribution pattern of these proteins was changed in tubules with altered spermatogenesis, as well as in some morphologically normal tubules. $\mathrm{N}$-cadherin and $\mathrm{Cx} 43$ were frequently localized in the form of irregular lines or distinct foci between the cells (Figures 1(b) and 1(j)), in the cytoplasm of Sertoli cells (Figures 1(b), 1(d), and 1(j)), or at the entire surfaces of Sertoli and germ cells (Figure 1(l)). $\beta$-catenin reactivity remained at the region of BTB, whereas loss of the staining was detected in the apical compartment of seminiferous epithelium (Figures 1(f) and 1(h)). In 18L:6D group signal intensities of all studied proteins were diminished following OP treatment when compared to the respective controls. In Leydig cells of OP60 males cytoplasmic staining for $\mathrm{Cx} 43$ was found (Figure $1(\mathrm{j})$-insert, l). No staining was detected when the antibody against $\mathrm{N}$-cadherin, $\beta$-catenin, or $\mathrm{Cx} 43$ was omitted (inserts in Figures 1(c), 1(g), and 1(l)).

Immunodetectable $\mathrm{N}$-cadherin, $\beta$-catenin, and $\mathrm{Cx} 43$ proteins were observed as single bands near the 127, 92, and $43 \mathrm{kDa}$ positions of the SDS gel, respectively, in testicular homogenates of the control voles and those treated with OP (Figure 2). In the testes of 18L : 6D males expression levels of $\mathrm{N}$-cadherin and $\beta$-catenin were significantly decreased only in OP60 animals when compared to the respective controls (Figures 2(a) and 2(b)), whereas $\mathrm{Cx} 43$ was reduced in both OP30 and OP60 groups (Figure 2(c)). In 6L:18D group an increase in the expression levels of all studied proteins was found. However, the increase was statistically significant only in case of $\mathrm{Cx} 43$ (Figure 2(c)).

Serum FSH concentration was higher in $18 \mathrm{~L}: 6 \mathrm{D}$ animals when compared with $6 \mathrm{~L}: 18 \mathrm{D}$ males. No significant influence of OP was seen on FSH concentrations in both 18L : 6D and $6 \mathrm{~L}: 18 \mathrm{D}$ groups (Figure 3 ).
3.2. Organ Culture. When OP was present in the culture medium at concentrations of 10,100 , and $500 \mathrm{mg} / \mathrm{L}$, in homogenates of testicular pieces from 18L:6D animals a progressive decline in $\mathrm{N}$-cadherin and $\mathrm{Cx} 43$ expression levels was obtained at all doses after $24 \mathrm{~h}$ of culture (Figures 4 (b) and 4(d)); however only higher concentrations (100 and $500 \mathrm{mg} / \mathrm{L}$ ) elicited statistically significant effect. Expression of $\beta$-catenin decreased following exposure to $500 \mathrm{mg} / \mathrm{L} \mathrm{OP}$, whereas lower doses had no effect. In testis explants of $6 \mathrm{~L}: 18 \mathrm{D}$ males protein expression levels were increased, but a relatively large variation in the expressions of $\mathrm{N}$-cadherin and $\beta$-catenin between the individual testes exposed to OP meant the differences were not statistically significant (Figures 4(b)$4(d))$.

An inhibitory experiment was performed using pure antiestrogen, ICI 182,780. Explants from 18L : 6D males were tested with $6 \mathrm{mg} / \mathrm{L}$ ICI alone for $24 \mathrm{~h} ; 100$ and $500 \mathrm{mg} / \mathrm{L} \mathrm{OP}$ alone for $24 \mathrm{~h}$; or combination of each dose of OP plus $6 \mathrm{mg} / \mathrm{L}$ ICI. Since ICI showed no discernible effect on proteins' expression, solvent-treated explants served as controls in this experiment. Coadministration of ICI did not block the effects of $\mathrm{OP}$ on $\mathrm{N}$-cadherin expression (Figure 5(a)). On the other hand, ICI partially reversed the OP-induced decrease in $\beta$ catenin and $\mathrm{Cx} 43$ in testicular fragments cultured in vitro (Figures 5(b) and 5(c)).

\section{Discussion}

To assess the effects of $\mathrm{OP}$ on junction proteins expression in bank vole testis in vivo and in vitro methods were used. In vivo experiments are required for understanding the action of tested chemical in the internal environment of the organism, where it undergoes various biochemical transformations, affecting their bioavailability and activity. It was reported that in mammals $\mathrm{OP}$ is metabolized by the liver to two glucuronide conjugates [21]. Glucuronidation of OP eliminates its estrogen-like activity; however glucuronides may be hydrolysed back to active compounds [22]. At doses that exceed the metabolization level, OP accumulates in various organs, particularly, in adipose tissue, liver, muscles, and brain $[23,24]$. Therefore, the effects of OP action are noted following administration of high doses or after chronic exposure, as it was demonstrated by data obtained in our and other laboratories $[17,25]$. In addition, the influence of OP on endogenous estrogens production might contribute to the effects observed in vivo [17].

In contrast, during in vitro organ culture of the testis the influence of extratesticular factors is avoided, while relationship among the cells remains intact and the interactions between the cells can be accurately evaluated [26]. Therefore, short-term organ culture was used to examine whether OP could exert direct and immediate effects on junction proteins expression in the cells of the seminiferous tubule.

The results presented herein demonstrate that exposure of male bank voles to $\mathrm{OP}$ has a potential to induce adverse effects on junction proteins in the testes. Interestingly, alterations in the expressions and localizations of these proteins appeared to be dependent on the length of the photoperiod. Our 
$18 \mathrm{~L}: 6 \mathrm{D}$
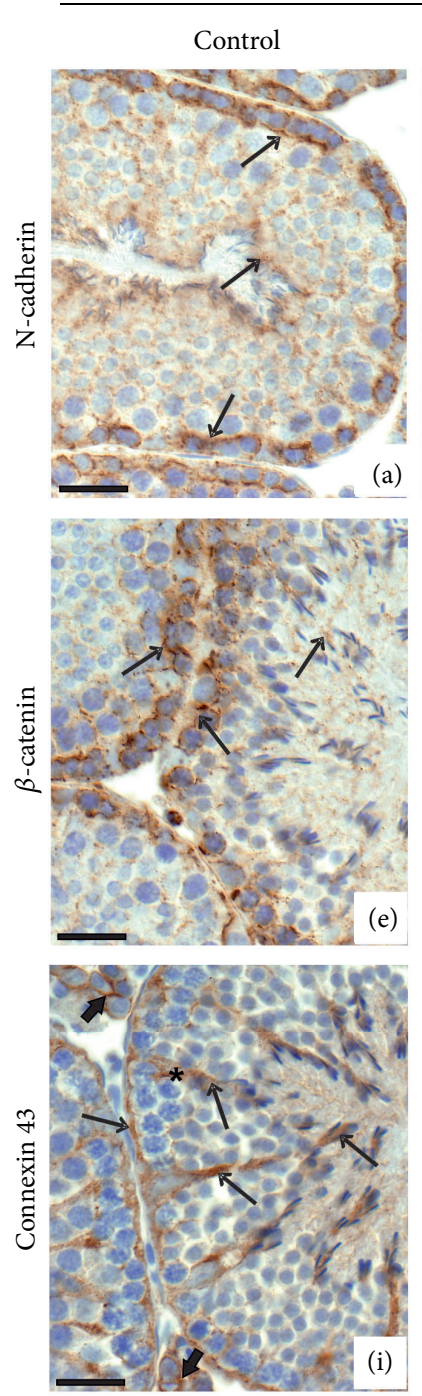
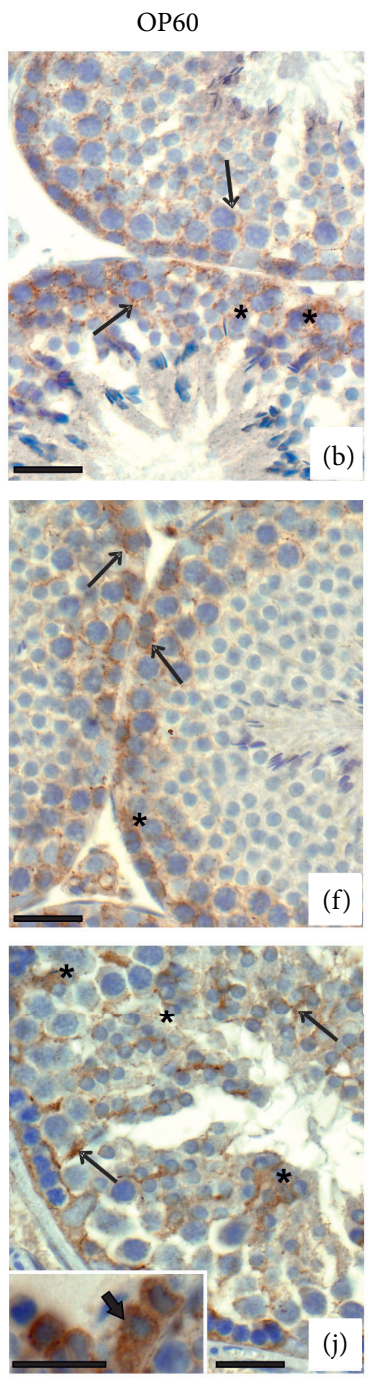

$6 \mathrm{~L}: 18 \mathrm{D}$

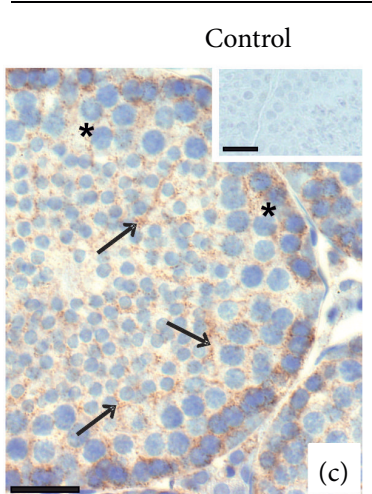

(c)

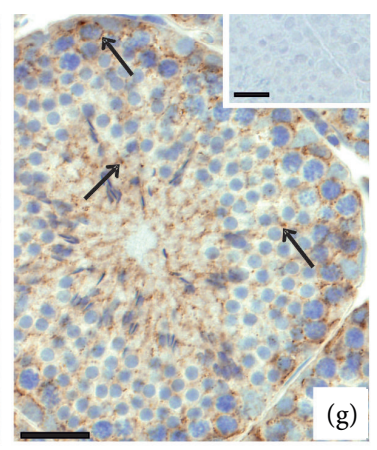

(g)

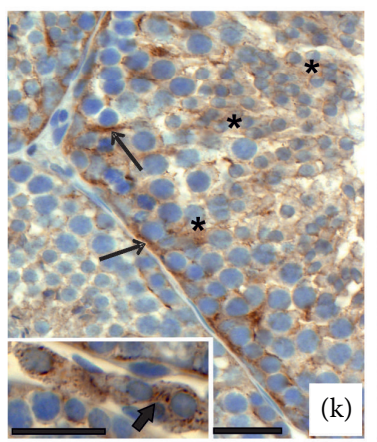

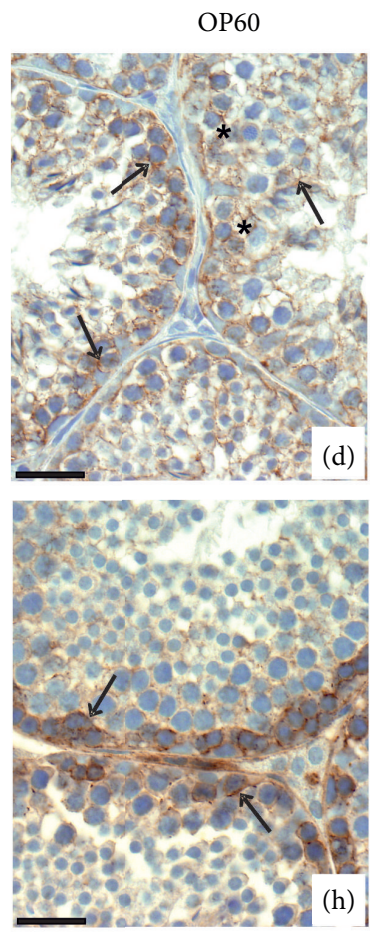

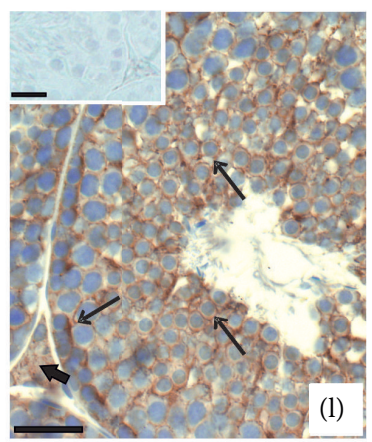

FIGURE 1: Immunohistochemical localization of N-cadherin (a)-(d), $\beta$-catenin (e)-(h), and connexin 43 (Cx43) (i)-(l) in the testes of bank voles kept in long $(18 \mathrm{~L}: 6 \mathrm{D})$ or short $(6 \mathrm{~L}: 18 \mathrm{D})$ photoperiod treated with vehicle (control) or 4-tert-octylphenol for 60 days $(\mathrm{OP} 60)$. Scale bars represent $20 \mu \mathrm{m}$. (a)-(d) Immunohistochemical localization of N-cadherin. (a) In control 18L:6D males strong, linear staining at the region of blood-testis barrier and discrete punctuate staining in the adluminal compartment is observed (arrows). (b) Reduced intensity and delocalization of the staining following OP60 treatment (arrows). (c) In control 6L:18D voles weak staining extends through much of the epithelium (arrows). (d) In OP60 tubules enhanced staining is visible (arrows). No signal was detected when anti-N-cadherin antibody was omitted (insert in (c)). (e)-(h) Immunohistochemical localization of $\beta$-catenin. (e) Typical distribution of $\beta$-catenin signal is seen in the basal compartment of seminiferous epithelium and at the regions of membrane apposition of adjacent Sertoli cell and elongated spermatids (arrows) in the testes of control 18L : 6D males. (f) Note decreased intensity of the staining at the blood-testis barrier site (arrows) and loss of the signal in the adluminal compartment in OP60 voles. (g) In the tubules of $6 \mathrm{~L}: 18 \mathrm{D}$ animals weak staining is dispersed in the seminiferous epithelium (arrows). (h) Increased staining intensity in the basal compartment in OP60 males (arrows). No signal was detected when anti- $\beta$-catenin antibody was omitted (insert in (g)). (i)-(l) Immunohistochemical localization of connexin 43 (Cx43). (i) In the tubules of control 18L : 6D males Cx43 is seen predominantly between Sertoli cells and spermatogonia or pachytene spermatocytes and in the cytoplasm of some Sertoli cells as well as at Sertoli cell-spermatid junctions (arrows). Note strong linear staining between Leydig cells (small arrows). (j) In OP60 males Cx43 signal is localized in the form of irregular lines or distinct foci between the cells (arrows) and sometimes in the cytoplasm of Sertoli cells (asterisks). Cytoplasmic staining is present in most Leydig cells (small arrow; insert). (k) In the tubules of 6L : 18D voles irregular and discontinuous signal is visible (arrows). Frequently, the staining is confined to the cytoplasm of the cells (asterisks). In Leydig cells, staining of moderate intensity is detected in the cytoplasm (small arrow; insert). (l) Note altered staining pattern in OP60 animals; signal visible at the entire surfaces of Sertoli and germ cells (arrows). Very week staining in Leydig cell cytoplasm (small arrow). No signal was detected when anti-Cx43 antibody was omitted (insert in (1)). 

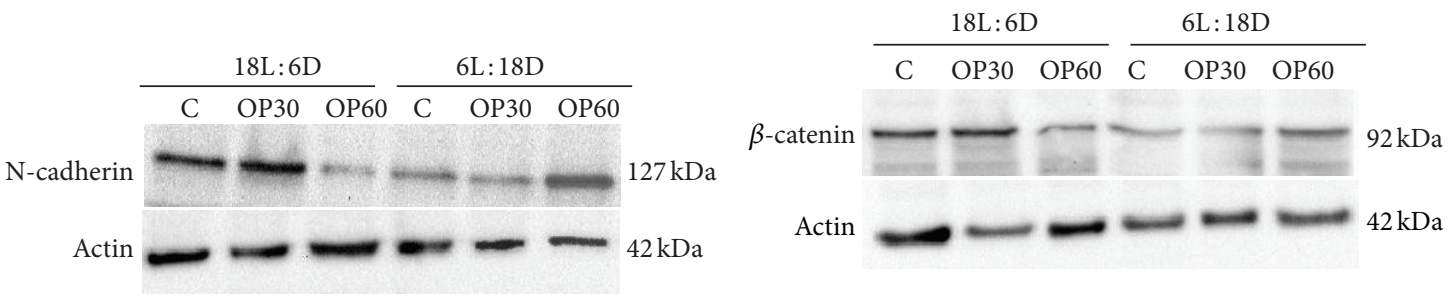

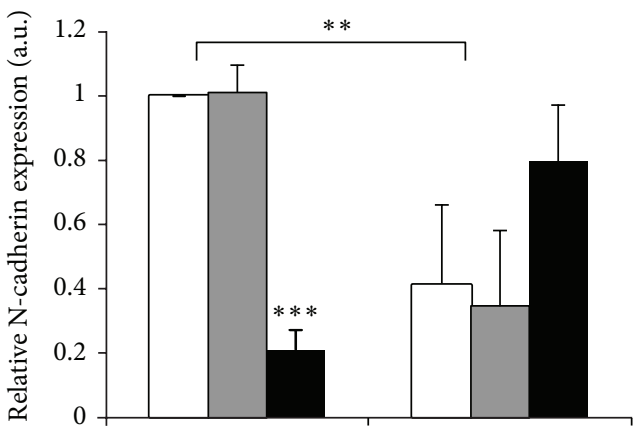

$18 \mathrm{~L}: 6 \mathrm{D}$

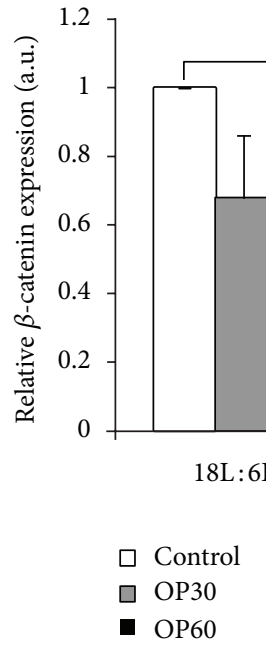

(a)

(b)
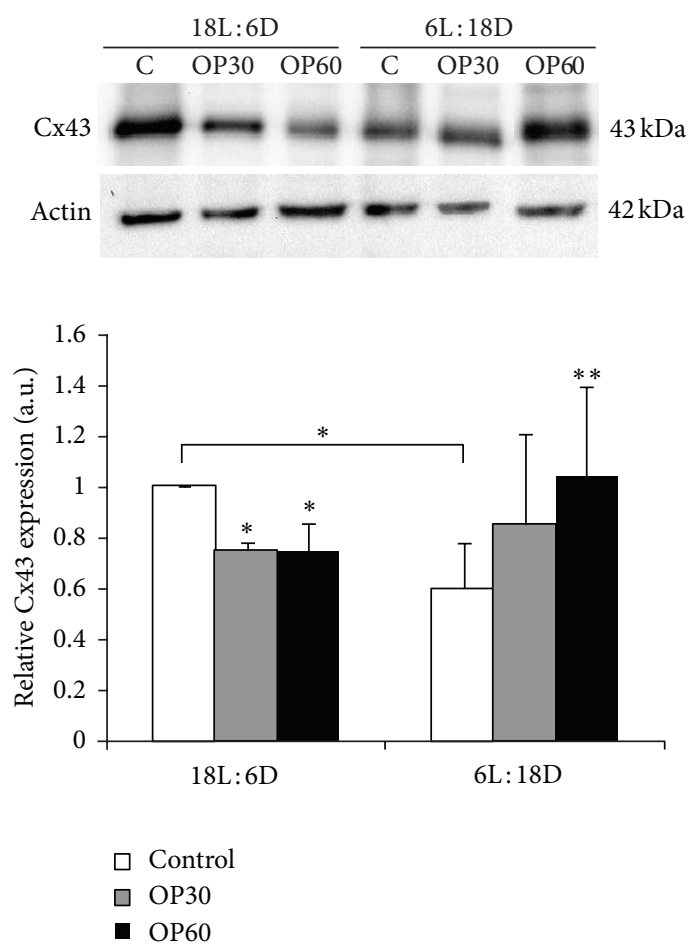

(c)

FIgURE 2: Representative Western blot analyses and relative N-cadherin (a), $\beta$-catenin (b), and connexin 43 (c) protein expression levels in testicular homogenates of bank voles kept in either long light cycles $(18 \mathrm{~L}: 6 \mathrm{D})$ or short light cycles $(6 \mathrm{~L}: 18 \mathrm{D})$ treated with vehicle $(n=6)$ or with 4-tert-octylphenol for 30 and 60 days (OP30, $n=6$; OP60, $n=6$ ). The relative amount of N-cadherin, $\beta$-catenin, and connexin 43 proteins normalized to $\beta$-actin. Data obtained from three separate analyses is expressed as mean $\pm \mathrm{SD}$. Significant differences from control values are denoted as ${ }^{*} P<0.05,{ }^{* *} P<0.01$, and ${ }^{* * *} P<0.001$. 


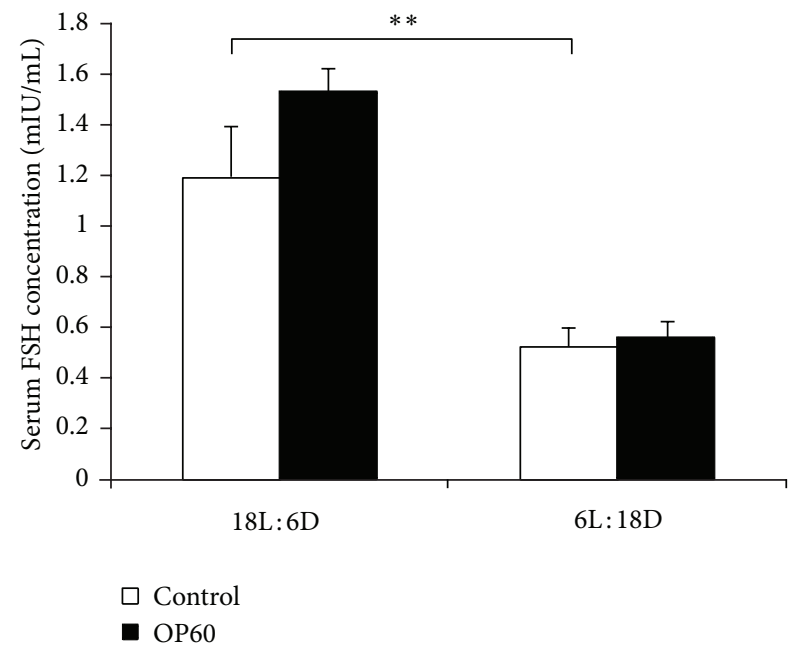

FIGURE 3: The effect of 4-tert-octylphenol treatment on FSH levels in the testes of $18 \mathrm{~L}: 6 \mathrm{D}$ and $6 \mathrm{~L}: 18 \mathrm{D}$ bank voles. Values are expressed as mean \pm SD. Asterisks indicate significant differences between control animals (control, $n=6 /$ each group) and males exposed to OP for 60 days (OP60, $n=6 /$ each group). Statistical significance: ${ }^{* *} P<0.01$.

results are the first reported on the influence of the length of the photoperiod on $\mathrm{N}$-cadherin and $\beta$-catenin proteins in the testis of seasonally breeding rodents. It should be noted that bank voles kept under long photoperiod (18L: 6D) show similar reproductive characteristics as those observed in the wild in reproductively active males during spring and summer, whereas animals exposed to short light regime $(6 \mathrm{~L}: 18 \mathrm{D})$ show regressive phase of reproduction that occurs in the wild voles during late autumn and winter. In the testes of males kept in short light cycles most of seminiferous tubules exhibit small or no lumen with not fully differentiated germ cells. Decrease in the level of plasma gonadotropins during the short photoperiod results in reduced testosterone production decreased expression and activity of steroidogenic enzymes and reduced expression of androgen receptor when compared to long-day animals $[17,27,28]$. The present study provides clear evidence that in bank voles also direct cell-cell interactions are regulated by length of the light cycle, since the expression and localization of protein markers of adherens and gap junctions are different in animals reared under different light conditions. We noticed that organization of $\mathrm{N}$-cadherin/ $\beta$-catenin and $\mathrm{Cx} 43$-based junctions in the seminiferous epithelium of $18 \mathrm{~L}: 6 \mathrm{D}$ males was consistent with the organization of morphologically mature junctions in the adult testes of continual breeders such as mice and rats $[11,13$, $29,30]$. On the contrary, in $6 \mathrm{~L}: 18 \mathrm{D}$ animals distribution of junction proteins was similar to those observed in immature or prepubertal males, in which weaker, punctuate, or cytoplasmic staining was dispersed in the basal and adluminal compartment of the epithelium [13,31]. This is in line with the results of Tarulli et al. [32], who reported that in short-day males of seasonally breeding Djungarian hamster Sertoli cells have characteristics of both adult and immature phenotypes, suggesting that they take on an intermediate or transitional state. It should be mentioned that early study by Pelletier [33] demonstrated the localization of $\mathrm{Cx} 43$ in another seasonal breeder, mink. In contrast to our observations, the author reported that during winter testicular regression immunoexpression of $\mathrm{Cx} 43$ is present only in the basal third of the epithelium. Such a result was presumably a consequence of performing less sensitive immunohistochemical method with the use of secondary antibody conjugated directly to peroxidase.

Disorganization and decreased expressions of $\mathrm{N}$ cadherin, $\beta$-catenin, and $\mathrm{Cx} 43$ proteins in $6 \mathrm{~L}: 18 \mathrm{D}$ bank vole males were accompanied with reduced FSH level in these animals.

There is evidence that FSH stimulates the formation of extensive inter-Sertoli cell adherens junctions; in the absence of FSH adherens junction puncta were observed in rat Sertoli cells in vitro, whereas the addition of FSH induced the reorganization of these puncta into adherens junction belts [34]. Also gap junction coupling and organization of $\mathrm{Cx} 43$ gap junction plaques between Sertoli cells in vitro appeared to be regulated by FSH and cAMP [35, 36]. Moreover, recent data on Djungarian hamsters indicate that gonadotropin suppression induced by short photoperiod disrupted distribution and expressions of tight junction proteins, and FSH replacement led to a rapid reorganization of these proteins [32]. Based on these data and our results we believe that in bank voles FSH could be a factor controlling adherens and gap junctions arrangement in the seminiferous epithelium during transition from reproductive quiescence to reproductive activity.

Despite numerous studies on testis histopathology of males treated with OP, very little is known about the alterations induced by this xenoestrogen on cell-cell junction molecules. In the only paper reporting the effects of OP on Sertoli cell junction proteins, Fiorini et al. [37] observed reduction in the levels of occludin, $\mathrm{N}$-cadherin, and $\mathrm{Cx} 43$ in the SerW3 Sertoli cell line treated with $0.2 \mu \mathrm{M}$ OP for $24 \mathrm{~h}$. In addition to its effect on protein levels, OP was able to delocalize the proteins from the membrane to the cytoplasmic compartment [37]. In the present study, it was shown that long-term in vivo OP treatment of adult bank voles also resulted in the reduction of $\mathrm{N}$-cadherin, $\beta$-catenin, and $\mathrm{Cx} 43$ proteins expressions and their delocalization, but only in the testes of males kept in long photoperiod. Surprisingly, in short-day animals slight increase of $\mathrm{Cx} 43(P<0.05), \mathrm{N}-$ cadherin, and $\beta$-catenin (statistically nonsignificant) levels was found. These differences appeared to be independent of FSH, since OP treatment did not change FSH concentrations neither in long-day nor in short-day animals. Thus, we hypothesize that OP affects junction proteins expression acting directly on the testis. To test this hypothesis we used organ culture model. We found that in testis explants cultured with OP for $24 \mathrm{~h}$ expression levels of all studied proteins were reduced in long-day voles and slightly elevated in short-day animals. Photoperiod-dependent effect of OP on junction proteins in bank vole testes was therefore maintained in in vitro conditions, indicating that hypothalamic-pituitary axis is not involved in this effect. 


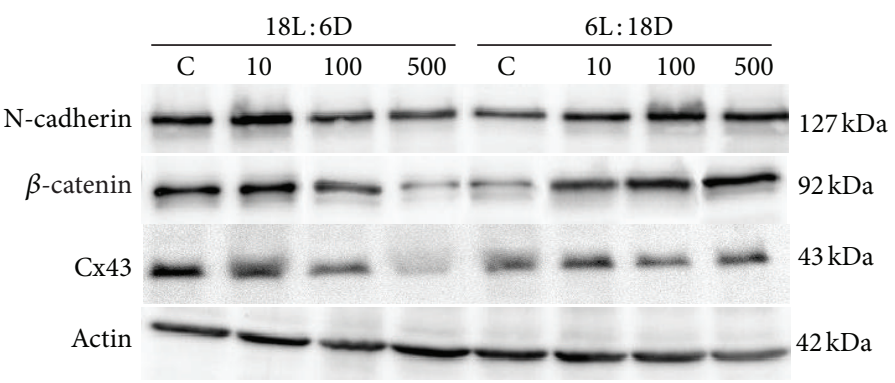

(a)

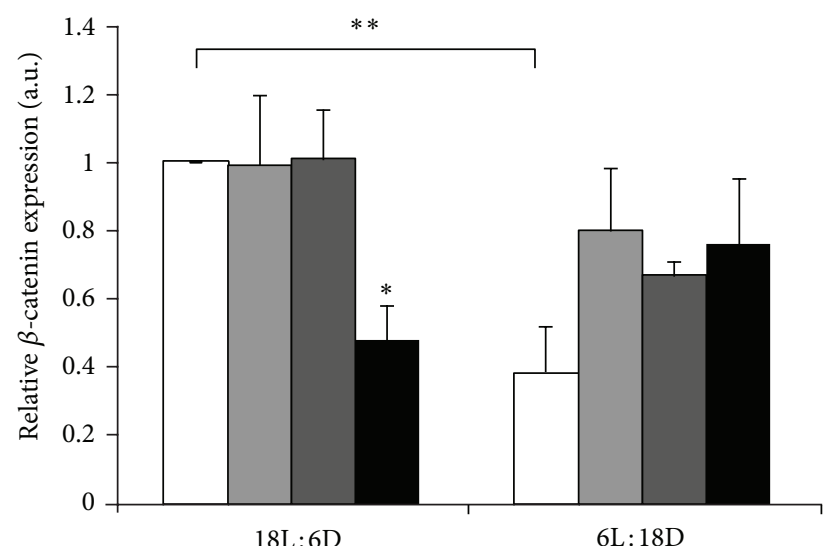

$\begin{array}{ll}\square \text { Control } & \square 100 \mathrm{mg} / \mathrm{lOP} \\ \square 10 \mathrm{mg} / \mathrm{lOP} & \square 500 \mathrm{mg} / \mathrm{lOP}\end{array}$

(c)

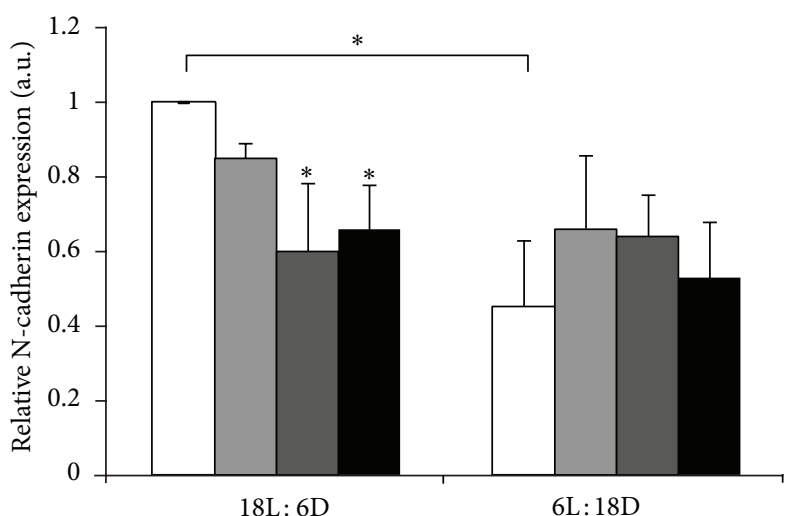
$\square$ Control
$\square 10 \mathrm{mg} / \mathrm{lOP}$
$100 \mathrm{mg} / \mathrm{lOP}$
- $500 \mathrm{mg} / \mathrm{lOP}$

(b)

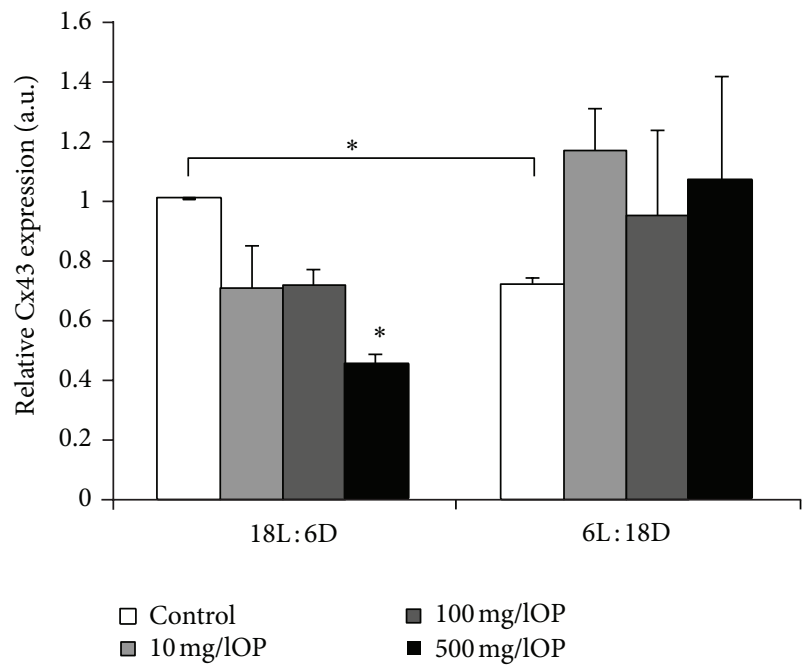

(d)

Figure 4: (a) Representative Western blot analysis of N-cadherin, $\beta$-catenin, and connexin 43 protein expression levels in homogenates of testis explants from bank voles kept in either long light cycles $(18 \mathrm{~L}: 6 \mathrm{D} ; n=8)$ or short light cycles $(6 \mathrm{~L}: 18 \mathrm{D} ; n=8)$. Explants were cultured in control medium (c) or in media containing 10,100 , or $500 \mathrm{mg} / \mathrm{L} 4$-tert-octylphenol for $24 \mathrm{~h}$. Anti- $\beta$-actin labeling served as an internal protein loading control. (b)-(d) The relative amount of $\mathrm{N}$-cadherin (b), $\beta$-catenin (c), and connexin 43 (d) proteins normalized to $\beta$-actin. Data obtained from three separate analyses is expressed as mean \pm SD. Significant differences from control values are denoted as ${ }^{*} P<0.05$ and ${ }^{* *} P<0.01$.

The reason for diverse responses of males kept in different light conditions to OP remains to be elucidated. Nevertheless, since in our previous studies on bank vole testis we found elevated estradiol concentrations and aromatase expression following OP exposure [17], it is possible that in short-day voles OP directly acting (as estrogen-like compound), or more likely through induction of local estradiol production, restores the expression levels of junction proteins. These hypothesis is based on our earlier observations that exposure to low dose of exogenous estradiol induced acceleration of the onset of spermatogenesis in voles kept under short light cycle conditions and on the finding that estrogens have FSH-independent stimulatory effect on spermatogenesis in photoregressed Siberian hamster [38, 39].
On the other hand, in long-day males, OP exerts negative effect on the expression of junction proteins, presumably by inducing supraphysiological estrogen level or action. Indeed, our previous studies revealed that in bank vole males treated with a high dose of estradiol disruption of testicular structure and tubular atrophy occurred [38]. Moreover, in rats exogenous estrogens appeared to affect cell-cell junctions in the testis; $17 \beta$-estradiol was shown to be disruptive to the BTB integrity, while $17 \alpha$-ethinylestradiol altered intercellular communication by disrupting gap junction functionality and $\mathrm{Cx} 43$ trafficking in cultured Sertoli cells as well as in isolated rat seminiferous tubules $[12,40]$.

It should be noted that in our study OP had the most rapid effects on $\mathrm{Cx} 43$ protein expression in the testes of $18 \mathrm{~L}: 6 \mathrm{D}$ 


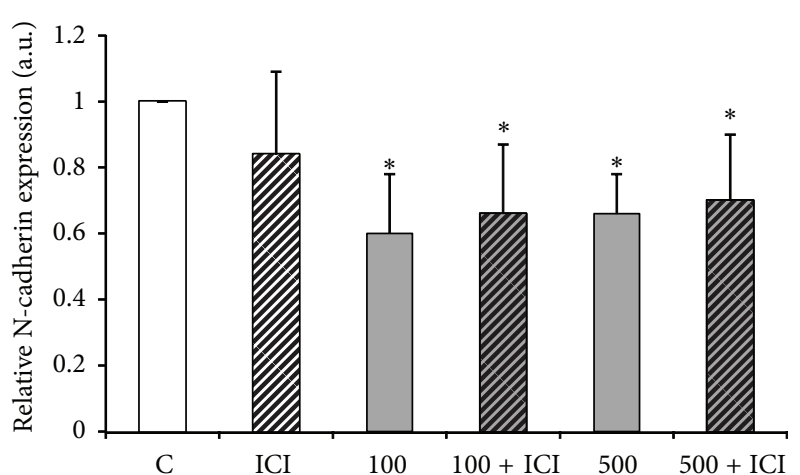

(a)

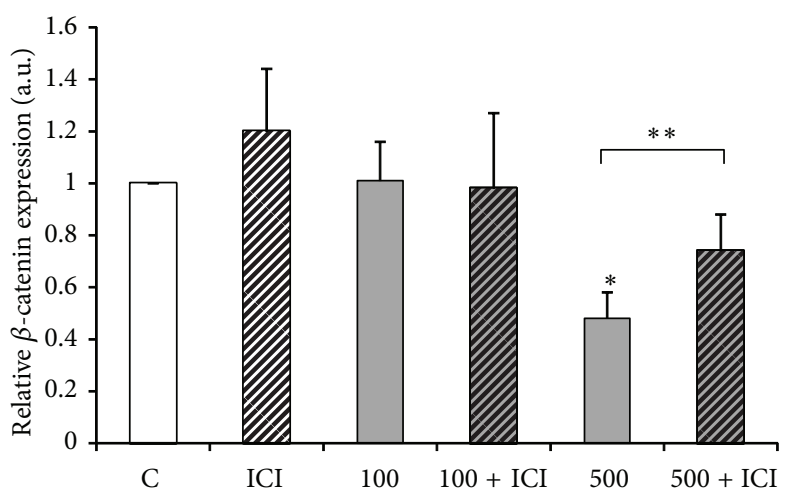

(b)

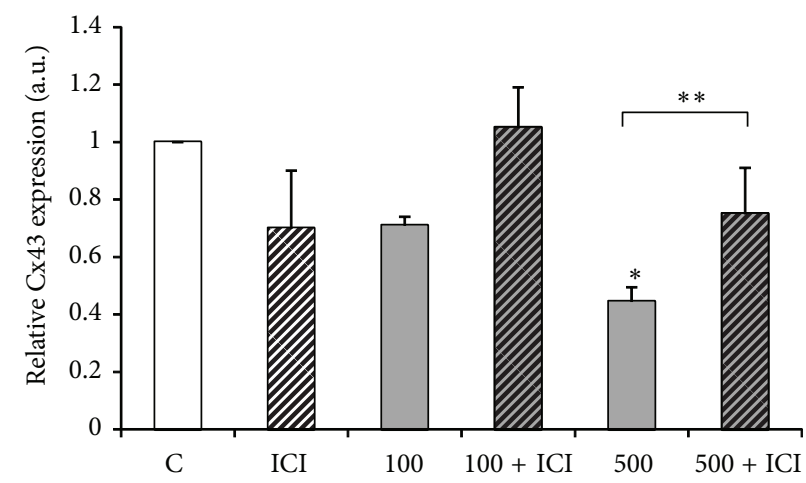

(c)

FIGURE 5: The effects of ICI 182,780 on octylphenol-induced decrease of N-cadherin (a), $\beta$-catenin (b) and connexin 43 (c) protein expression in homogenates of testis explants from bank voles kept in long light cycles $(n=8)$. Explants were cultured in control medium (c) or in media containing $6 \mathrm{mg} / \mathrm{L} \mathrm{ICI} \mathrm{182,780} \mathrm{(ICI);} 100$ or $500 \mathrm{mg} / \mathrm{mL}$ 4-tert-octylphenol (100, 500); 100 or $500 \mathrm{mg} / \mathrm{mL}$ 4-tert-octylphenol and $6 \mathrm{mg} / \mathrm{L} \mathrm{ICI}$ $182,780(100+\mathrm{ICI} ; 500+\mathrm{ICI})$ for $24 \mathrm{~h}$. Graphs represent the relative amount of $\mathrm{N}$-cadherin (b), $\beta$-catenin (c), and connexin 43 (d) protein normalized to $\beta$-actin. Data obtained from three separate analyses is expressed as mean \pm SD. Significant differences from control values are denoted as ${ }^{*} P<0.05$ and ${ }^{* *} P<0.01$.

males (visible just after 30-day exposure). This observation argues for the recent hypothesis that $\mathrm{Cx} 43$ is one of the main targets for endocrine disruptors and that impaired $\mathrm{Cx} 43$ expression affects other proteins of the BTB [41].

The question arises as to the mechanism of $\mathrm{OP}$ action on junction proteins in the seminiferous tubules. To determine whether this actions was mediated through binding to ER $\alpha$ or ER $\beta$, testicular explants from 18L:6D males were treated concomitantly with a pure estrogen antagonist, ICI 187780 $(6 \mathrm{mg} / \mathrm{L})$, and increasing OP concentrations (10 to $500 \mathrm{mg} / \mathrm{L})$. We found that $\beta$-catenin and Cx43 OP-induced decrease was partially blocked by ICI, suggesting that the biological effects of $\mathrm{OP}$ on the expression of these proteins involve an ERmediated response. On the other hand, the influence of OP on $\mathrm{N}$-cadherin does not appear to be mediated through the classic nuclear ERs, since ICI did not alter the effects of OP. Several earlier papers reported that also some other effects of OP were not mediated through the ER, possibly involving interactions with membrane components or receptors. For example, Murono et al. $[42,43]$ described the effects of OP on the conversion of progesterone to testosterone and hCGstimulated testosterone biosynthesis as independent of ER $\alpha$ and $\mathrm{ER} \beta$.

It cannot be, however, excluded that after the relatively short incubation period $(24 \mathrm{~h})$ some amounts of the proteins are not degraded and still exist in the cultured tissue, even if the mRNA level was downregulated. Therefore, further studies including sequencing of bank vole genes and the application of RT-PCR method are needed to verify data regarding mechanisms of OP action on junction proteins expression in the bank vole testes.

\section{Conclusion}

In this study we demonstrated that in seasonally breeding bank vole organization of adherens and gap junctions as well as the expression of junction proteins is related to the length of photoperiod and, in consequence, to the reproductive status of the animal. In addition, we found that reproductive status may determine response to OP. Finally, we found that 
alterations in cadherin/catenin and Cx43-based junction in the testes following OP exposure may partially result from activation of $\mathrm{ER} \alpha$ and/or $\mathrm{ER} \beta$ signaling pathway.

\section{Conflicts of Interests}

The authors declare that there is no conflicts of interests.

\section{Acknowledgment}

This work was financially supported by the Ministry of Science and Higher Education, a Grant no. N N303816640.

\section{References}

[1] A. Bergè, M. Cladière, J. Gasperi et al., "Meta-analysis of environmental contamination by alkylphenols," Environmental Science and Pollution Research, vol. 19, no. 9, pp. 3798-3819, 2012.

[2] A. M. Calafat, X. Ye, L. Y. Wong, J. A. Reidy, and L. L. Needham, "Exposure of the U.S. population to bisphenol A and 4-tertiaryoctylphenol: 2003-2004," Environmental Health Perspectives, vol. 116, no. 1, pp. 39-44, 2008.

[3] E. Diamanti-Kandarakis, J. P. Bourguignon, L. C. Giudice et al., "Endocrine-disrupting chemicals: an endocrine society scientific statement," Endocrine Reviews, vol. 30, no. 4, pp. 293342, 2009.

[4] S. J. Kwack, O. Kwon, H. S. Kim et al., "Comparative evaluation of alkylphenolic compounds on estrogenic activity in vitro and in vivo," Journal of Toxicology and Environmental Health A, vol. 65, no. 5-6, pp. 419-431, 2002.

[5] C. S. Watson, Y. J. Jeng, and M. Y. Kochukov, "Nongenomic signaling pathways of estrogen toxicity," Toxicological Sciences, vol. 115, no. 1, pp. 1-11, 2010.

[6] "European Commission. Directive 2000/60/EC of the European Parliament and of the Council of 23 October 2000 Establishing a Framework for Community Action in the Field of Water Policy," Office Journal L 327/1.

[7] A. David, H. Fenet, and E. Gomez, "Alkylphenols in marine environments: distribution monitoring strategies and detection considerations," Marine Pollution Bulletin, vol. 58, no. 7, pp. 953960, 2009.

[8] S. Goossens and F. Van Roy, "Cadherin-mediated cell-cell adhesion in the testis," Frontiers in Bioscience, vol. 10, no. 1, pp. 398-419, 2005.

[9] H. H. N. Yan, D. D. Mruk, W. M. Lee, and C. Y. Cheng, "Blood -testis barrier dynamics are regulated by testosterone and cytokines via their differential effects on the kinetics of protein endocytosis and recycling in Sertoli cells," FASEB Journal, vol. 22, no. 6, pp. 1945-1959, 2008.

[10] R. Brehm, M. Zeiler, C. Rüttinger et al., "A sertoli cell-specific knockout of connexin 43 prevents initiation of spermatogenesis," American Journal of Pathology, vol. 171, no. 1, pp. 19-31, 2007.

[11] D. Carette, K. Weider, J. Gilleron et al., "Major involvement of connexin 43 in seminiferous epithelial junction dynamics and male fertility," Developmental Biology, vol. 346, no. 1, pp. 54-67, 2010.

[12] M. W. Li, D. D. Mruk, W. M. Lee, and C. Y. Cheng, "Disruption of the blood-testis barrier integrity by bisphenol A in vitro: is this a suitable model for studying blood-testis barrier dynamics?" International Journal of Biochemistry and Cell Biology, vol. 41, no. 11, pp. 2302-2314, 2009.
[13] S. Salian, T. Doshi, and G. Vanage, "Neonatal exposure of male rats to Bisphenol A impairs fertility and expression of sertoli cell junctional proteins in the testis," Toxicology, vol. 265, no. 1-2, pp. 56-67, 2009.

[14] J. Aravindakshan and D. G. Cyr, "Nonylphenol alters connexin 43 levels and connexin 43 phosphorylation via an inhibition of the p38-mitogen-activated protein kinase pathway," Biology of Reproduction, vol. 72, no. 5, pp. 1232-1240, 2005.

[15] Q. Bian, J. Qian, L. Xu, J. Chen, L. Song, and X. Wang, “The toxic effects of 4-tert-octylphenol on the reproductive system of male rats," Food and Chemical Toxicology, vol. 44, no. 8, pp. 1355-1361, 2006.

[16] A. Hossaini, M. Dalgaard, A. M. Vinggaard, P. Pakarinen, and J. J. Larsen, "Male reproductive effects of octylphenol and estradiol in Fischer and Wistar rats," Reproductive Toxicology, vol. 17, no. 5, pp. 607-615, 2003.

[17] A. Hejmej, M. Kotula-Balak, J. Galas, and B. Bilińska, "Effects of 4-tert-octylphenol on the testes and seminal vesicles in adult male bank voles," Reproductive Toxicology, vol. 31, no. 1, pp. 95105, 2011.

[18] S. K. Kim, J. H. Kim, H. J. Lee, and Y. D. Yoon, "Octylphenol reduces the expressions of steroidogenic enzymes and testosterone production in mouse testis," Environmental Toxicology, vol. 22, no. 5, pp. 449-458, 2007.

[19] T. E. Haavisto, N. A. Adamsson, S. A. Myllymäki, J. Toppari, and J. Paranko, "Effects of 4-tert-octylphenol, 4-tert-butylphenol, and diethylstilbestrol on prenatal testosterone surge in the rat," Reproductive Toxicology, vol. 17, no. 5, pp. 593-605, 2003.

[20] A. . Hejmej, I. Kopera, M. Kotula-Balak, M. Lydka, M. Lenartowicz, and B. Bilinska, "Are expression and localization of tight and adherens junction proteins in testes of adult boar affected by foetal and neonatal exposure to flutamide?" International Journal of Andrology, vol. 35, no. 3, pp. 340-352, 2012.

[21] S. Nomura, T. Daidoji, H. Inoue, and H. Yokota, "Differential metabolism of 4-n- and 4-tert-octylphenols in perfused rat liver," Life Sciences, vol. 83, no. 5-6, pp. 223-228, 2008.

[22] G. J. Moffat, A. Burns, J. Van Miller, R. Joiner, and J. Ashby, "Glucuronidation of nonylphenol and octylphenol eliminates their ability to activate transcription via the estrogen receptor," Regulatory Toxicology and Pharmacology, vol. 34, no. 2, pp. 182187, 2001.

[23] H. Certa, N. Fedtke, H. J. Wiegand, A. M. F. Müller, and H. M. Bolt, "Toxicokinetics of p tert octylphenol in male Wistar rate," Archives of Toxicology, vol. 71, no. 1-2, pp. 112-122, 1996.

[24] M. Bianco, L. Mita, M. Portaccio et al., "Differential accumulation levels in the brain of rats exposed to the endocrine disruptor 4-tert-octylphenol (OP)," Environmental Toxicology and Pharmacology, vol. 31, no. 1, pp. 198-204, 2011.

[25] C. A. Blake, F. R. Boockfor, J. U. Nair-Menon, C. F. Millette, S. S. Raychoudhury, and G. L. McCoy, "Effects of 4-tert-octylphenol given in drinking water for 4 months on the male reproductive system of Fischer 344 rats," Reproductive Toxicology, vol. 18, no. 1, pp. 43-51, 2004.

[26] J. H. Resau, K. Sakamoto, J. R. Cottrell, E. A. Hudson, and S. J. Meltzer, "Explant organ culture: a review," Cytotechnology, vol. 7, no. 3, pp. 137-149, 1991.

[27] B. Bilinska, E. Drag, and B. Schmalz-Fraczek, "Immunolocalization of androgen receptors in testicular cells during postnatal development of the bank vole (Clethrionomys glareolus, S.)," Tissue and Cell, vol. 31, no. 6, pp. 621-626, 1999. 
[28] T. Teräväinen and K. M. Tähkä, "Photoperiod-induced changes in the testicular metabolism of [4-14C]17 $\alpha$-hydroxyprogesterone in the bank vole (Clethrionomys glareolus)," Journal of Reproduction and Fertility, vol. 74, no. 2, pp. 625-630, 1985.

[29] A. Beardsley and L. O'Donnell, "Characterization of normal spermiation and spermiation failure induced by hormone suppression in adult rats," Biology of Reproduction, vol. 68, no. 4, pp. 1299-1307, 2003.

[30] J. H. Lee, K. W. Choi, S. J. Lee, and M. C. Gye, "Expression of $\beta$ catenin in human testes with spermatogenic defects," Archives of Andrology, vol. 51, no. 4, pp. 271-276, 2005.

[31] I. Kopera, M. Durlej, A. Hejmej et al., "Effects of pre- and postnatal exposure to flutamide on connexin 43 expression in testes and ovaries of prepubertal pigs," European Journal of Histochemistry, vol. 54, no. 2, p. e15, 2010.

[32] G. A. Tarulli, S. J. Meachem, S. Schlatt, and P. G. Stanton, "Regulation of testicular tight junctions by gonadotrophins in the adult Djungarian hamster in vivo," Reproduction, vol. 135, no. 6, pp. 867-877, 2008.

[33] R. M. Pelletier, "The distribution of connexin 43 is associated with the germ cell differentiation and with the modulation of the Sertoli cell junctional barrier in continual (guinea pig) and seasonal breeders' (mink) testes," Journal of Andrology, vol. 16, no. 5, pp. 400-409, 1995.

[34] P. Sluka, L. O'Donnell, J. R. Bartles, and P. G. Stanton, "FSH regulates the formation of adherens junctions and ectoplasmic specialisations between rat Sertoli cells in vitro and in vivo," Journal of Endocrinology, vol. 189, no. 2, pp. 381-395, 2006.

[35] J. Gilleron, D. Carette, F. Carpentier, D. Segretain, and G. Pointis, "Three-dimensional analysis of connexin 43 gap junction in the ex vivo rat seminiferous tubules: short-term effects of hormonal effectors," Microscopy Research and Technique, vol. 72, no. 11, pp. 845-855, 2009.

[36] F. Pluciennik, M. Joffre, and J. Deleze, "Follicle-stimulating hormone increases gap junction communication in Sertoli cells from immature rat testis in primary culture," Journal of Membrane Biology, vol. 139, no. 2, pp. 81-96, 1994.

[37] C. Fiorini, A. Tilloy-Ellul, S. Chevalier, C. Charuel, and G. Pointis, "Sertoli cell junctional proteins as early targets for different classes of reproductive toxicants," Reproductive Toxicology, vol. 18, no. 3, pp. 413-421, 2004.

[38] M. Gancarczyk, A. Paziewska-Hejmej, S. Carreau, Z. Tabarowski, and B. Bilińska, "Dose- and photoperioddependent effects of $17 \beta$-estradiol and the anti-estrogen ICI 182,780 on testicular structure, acceleration of spermatogenesis, and aromatase immunoexpression in immature bank voles," Acta Histochemica, vol. 106, no. 4, pp. 269-278, 2004.

[39] T. R. Pak, G. R. Lynch, and P. S. Tsai, "Estrogen accelerates gonadal recrudescence in photo-regressed male Siberian hamsters," Endocrinology, vol. 143, no. 10, pp. 4131-4134, 2002.

[40] M. Tramoni, J. Gilleron, K. Tahiri et al., "Contraceptive steroids from pharmaceutical waste perturbate junctional communication in Sertoli cells," Biochimie, vol. 91, no. 11-12, pp. 1366-1375, 2009.

[41] G. Pointis, J. Gilleron, D. Carette et al., "Testicular connexin 43, a precocious molecular target for the effect of environmental toxicants on male fertility," Spermatogenesis, vol. 1, no. 4, pp. 303-317, 2011

[42] E. P. Murono, R. C. Derk, and J. H. De León, “Octylphenol inhibits testosterone biosynthesis by cultured precursor and immature Leydig cells from rat testes," Reproductive Toxicology, vol. 14, no. 3, pp. 275-288, 2000.
[43] E. P. Murono, R. C. Derk, and J. H. De León, "Differential effects of octylphenol, $17 \beta$-estradiol, endosulfan, or bisphenol A on the steroidogenic competence of cultured adult rat Leydig cells," Reproductive Toxicology, vol. 15, no. 5, pp. 551-560, 2001. 


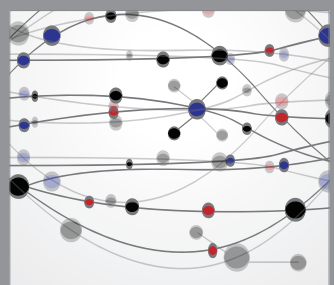

The Scientific World Journal
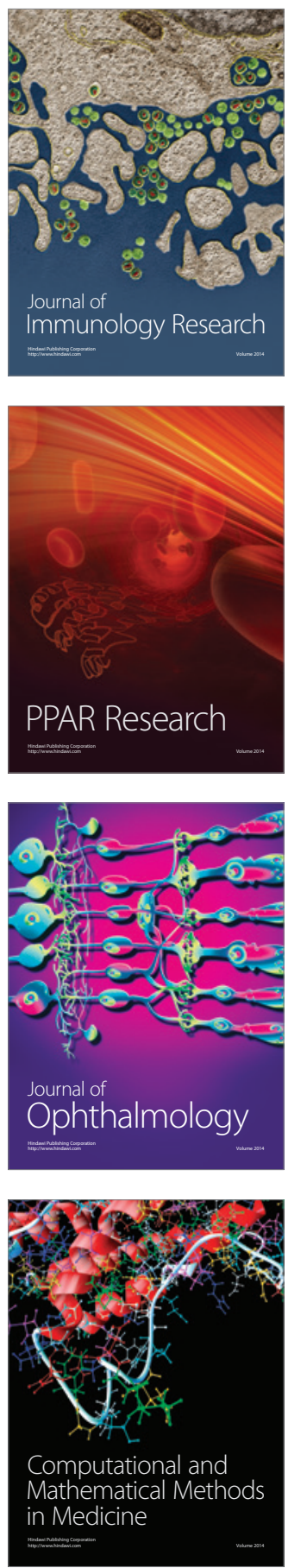

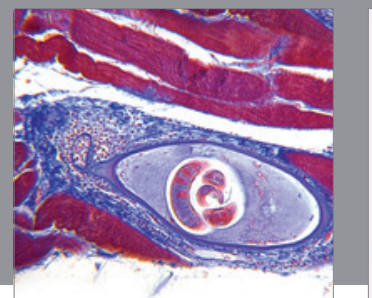

Gastroenterology

Research and Practice
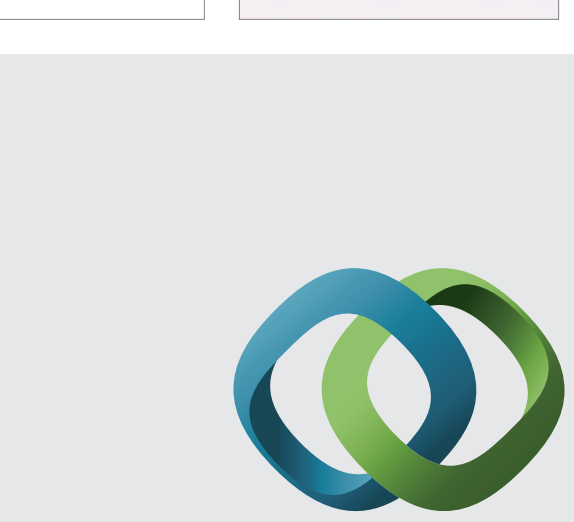

\section{Hindawi}

Submit your manuscripts at

http://www.hindawi.com
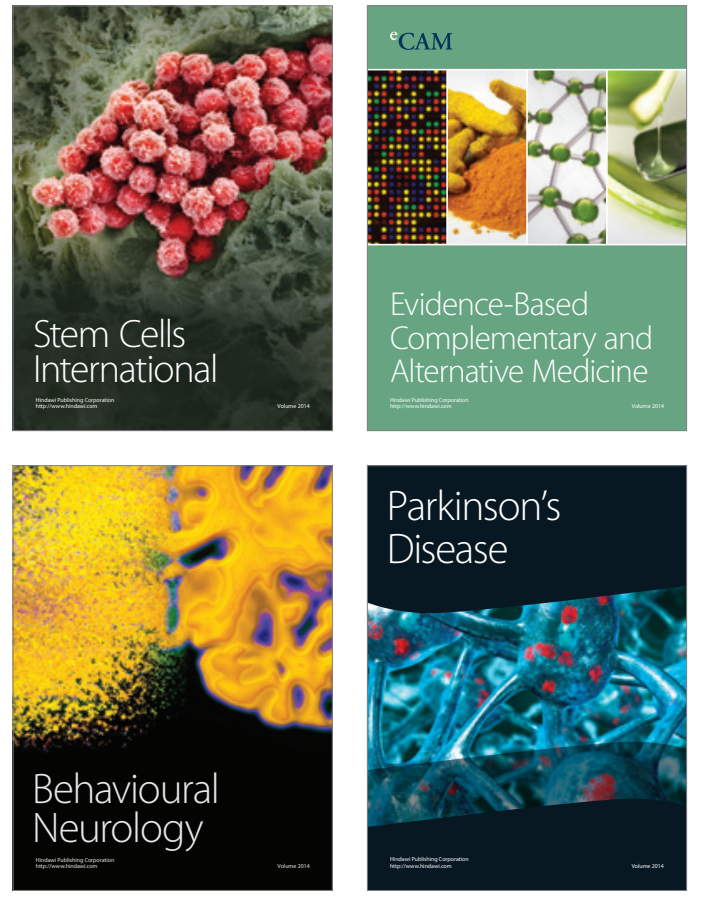
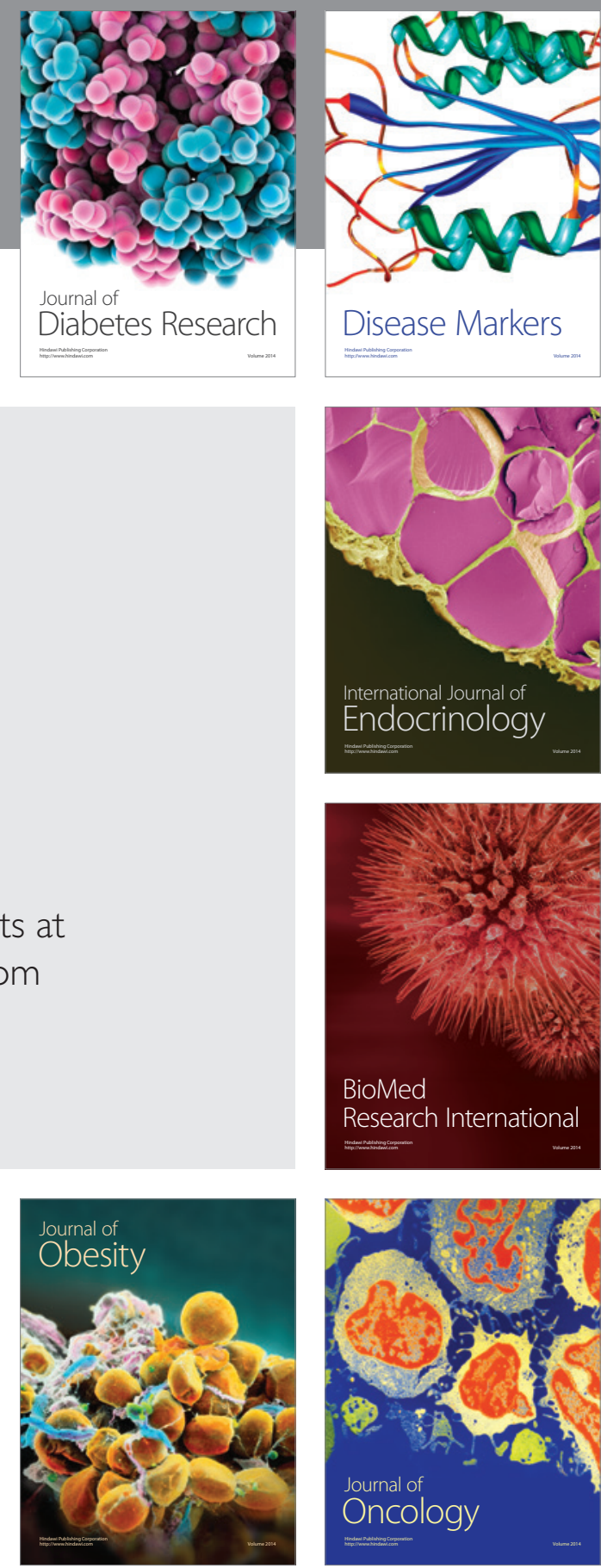

Disease Markers
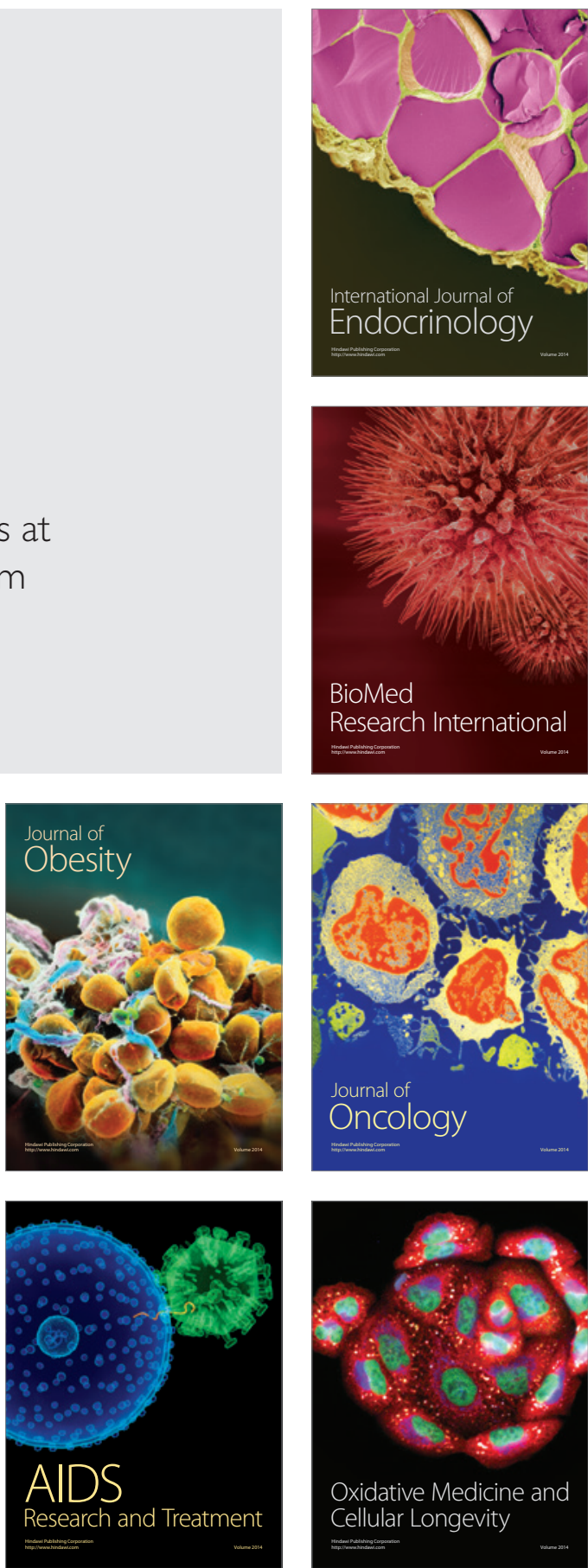